\title{
Determination of Total Ammonia in Mainstream Smoke*
}

by

\author{
Chorng B. Huang, Ron Bassfield, Bettie Dabney, and Frank Hsu
}

RD \& E Center, Philip Morris, USA, P. O. Box 26583, Richmond, Virginia, USA.

\section{SUMMARY}

Ammonia is generated in mainstream smoke (MSS) from multiple precursors in tobacco such as amino acids, proteins, nitrates and ammonium salts. Ammonia derived from both the particulate and vapor phases is measured with the particulate phase contributing greater than $80 \%$ of the total ammonia. The general approach of the analytical methods involved the collection of MSS by either electrostatic precipitation (EP) or impingers with acidic solution combined with Cambridge filters (CF, 44 or $92 \mathrm{~mm}$ ) and the analysis of ammonium cations by ion chromatography (IC) with a conductivity detector. The available results from both internal testing and external literature for 1R4F Kentucky reference cigarettes, smoked under Federal Trade Commission (FTC) puffing conditions, showed a wide range of yields from approximately 5 to $18 \mu \mathrm{g} / \mathrm{cig}$ of ammonia. To investigate possible causes for this wide range and to optimize the analytical method, several parameters deemed critical to the results were studied using 1R4F. They include the type of acids (hydrochloric acid, sulfuric acid and malic acid), acid strength (0.005 $M$ to $0.1 M)$, trapping efficiency and sample stability. The study showed that the type and concentration of acids was not significantly related to the total ammonia content in MSS. The study also indicated that the size and type of trapping devices, such as CF pads, acid treated CF pads and EP tube, did not significantly affect the trapping efficiency. [Beitr. Tabakforsch. Int. 20 (2003) 389-393]

\section{ZUSAMMENFASSUNG}

Ammonik wird im Hauptstromrauch (HSR) von Zigaretten aus zahlreichen Vorläufersubstanzen im Tabak gebildet, wie z.B. Aminosäuren, Proteinen, Nitraten und Ammoniumsalzen. Ammonik wurde in der Gas- und Partikelphase gemessen, wobei die Partikelphase mehr als $80 \%$ des gesamten Ammoniaks lieferte. Zum allgemeinen Vorgehen bei den analytischen Methoden gehörte das Sammeln des HSR durch elektrostatische Niederschlagung oder durch Waschflaschen mit saurer Lösung kombiniert mit Cambridge
Filtern (44 oder $92 \mathrm{~mm}$ ) sowie die Analyse der AmmoniumKationen durch Ionenchromatographie (IC) mit Leitfähigkeitsdetektor. Die Ergebnisse aus eigenen Versuchen und der Literatur für die nach Federal Trade Commission (FTC) Bedingungen abgerauchten 1R4F Kentucky Referenzzigaretten wiesen eine große Spannbreite von ungefähr 5 bis 18 $\mu \mathrm{g} /$ Zigarette auf. Um näheres über die Gründe für diese große Spannbreite zu erfahren und um die analytische Methode zu optimieren, wurden mehrere Parameter, die für die Ergebnisse als wichtig erachtet wurden, unter Verwendung der 1R4F Zigarette untersucht. Zu diesen zählten die Art der Säure (Salzsäure, Schwefelsäure und Apfelsäure), die Konzentration der Säure $(0,005 M$ bis $0,1 M)$, die Effizienz der Auffangvorrichtung und die Stabilität der Probe. Die Art und Konzentration der Säure führte zu keinen signifikanten Unterschieden beim Gesamtammoniak im HSR. Die Untersuchungen zeigten des weiteren, dass die Größe und Art der Auffangvorrichtung, wie Cambridge Filter, mit Säure behandelte Cambridge Filter und elektrostatische Fallen zu keinen signifikanten Unterschieden bezüglich der Auffangeffizienz führten. [Beitr. Tabakforsch. Int. 20 (2003) 389-393]

\section{RESUME}

L'ammoniac est généré dans la fumée du courant principal (CP) à partir de multiples précurseurs présents dans le tabac, comme les acides aminés, les protéines, les nitrates et sels d' ammonium. L' ammoniac a été dosé dans les phases particulaire et gazeuse, la phase particulaire contri buant pour plus de $80 \%$ de l' ammoniac total. L' approche générale des méthodes analytiques comprend la collecte du CP par précipitation électrique ou par barboteur avec une solution acide combinée aux filtres Cambridge (44 ou 92 $\mathrm{mm}$ ) et 1 ' analyse des cations ammonium par chromatographie d' ions avec détection par conductivité. Les résultats obtenus dans cette étude ou dans la littérature publiée sur les cigarettes Kentucky 1R4F, fumées sous les conditions normalisées FTC (Federal Trade Commission), révèlent des rendements en ammoniac variant de 5 à 18 $\mu \mathrm{g} / \mathrm{cig}$. Pour examiner les causes de cette variation et pour 
optimiser les méthodes analytiques, plusieurs paramètres considérés comme cruciaux pour les résultats ont été examinés. Ceux-ci comprennent le type d' acide (acides chlorhydrique, sulfurique et malique), la force de l' acide $(0.005 \mathrm{M})$, l' efficacité de piégeage et la stabilité de l' échantillon. Le type et la concentration de l' acide n' ont pas d' impact significatif sur le rendement total en ammoniac dans le $\mathrm{CP}$ de la fumée. Les résultats indiquent également que la taille et le type des dispositifs de piégeage, tels que les filtres Cambridge, les filtres Cambridge traités à l'acide et le tube à précipitation électrostatique, n' entraînent pas de différences significatives de l' efficacité du piégeage. [Beitr. Tabakforsch. Int. 20 (2003) 389-93]

\section{INTRODUCTION}

Ammonia, the basic trace gas in the atmosphere, is derived mainly from biogenic decomposition of organic materials in the fertilized fields. In cigarette smoke, ammonia appears from a variety of sources in tobacco. Studies have demonstrated that the major precursors for ammonia are nitrogen oxides resulting from decomposition of tobacco nitrate, amino acids, proteins and other nitrogenous materials in the burning cone of cigarettes (1). The amount of these various precursors depends on the tobacco type and the method of curing employed. Since 1982, several studies of mainstream smoke (MSS) in search of constituents reported that cigarette smoke contains approximately 4,000 individual chemicals (2). Ammonia is one of the major constituents in MSS and sidestream smoke (SSS). Concentrations of ammonia have been reported from 5-200 $\mu \mathrm{g} / \mathrm{cig}$ in MSS and up to about $14 \mathrm{mg} / \mathrm{cig}$ in SSS $(3,4)$. Ion chromatography (IC), which is capable of separating and detecting ionic species from various media, is an appropriate analytical technique for total ammonia determination in MSS.

\section{EXPERIMENTAL AND PROCEDURE}

\section{Instrument and apparatus}

The Dionex DX-500 IC system (Dionex, Sunnyvale, CA, USA) consisted of a quaternary gradient pump (GP40), a chromatographic oven (LC 20), an electrochemical detector (ED40), an eluent generator (EG40) and an autosampler (AS3500). The eluent was electrolytically suppressed with a cation self-regenerating suppressor. The sample loop used was $100 \mu \mathrm{L}$. The instrument conditions for the analysis were as follows:

Condition 1 - A Dionex IonPac $\AA$ CS12 column and a Dionex IonPac ${ }^{\circledR}$ CG12 guard column $(4 \times 50 \mathrm{~mm})$ were used. A solution of $12 \mathrm{mM}$ methanesulfonic acid was prepared and used as the eluent. The flow rate was set at $1.0 \mathrm{~mL}$ per minute. A $100 \mu \mathrm{L}$ aliquot of MSS samples was injected and analyzed using a conductivity detector.

Condition 2 - A Dionex IonPac ${ }^{\circledR}$ CS12A column and a Dionex IonPac ${ }^{\circledR}$ CG12A guard column $(4 \times 50 \mathrm{~mm})$ were used. A solution of $22 \mathrm{mM}$ sulfuric acid was prepared and used as the eluent. The flow rate was set at $1.0 \mathrm{~mL}$ per minute. A $100 \mu \mathrm{L}$ aliquot of MSS samples was injected and analyzed using a conductivity detector.
A Borgwaldt 20-port smoking machine was set up to generate the standard Federal Trade Commission (FTC) puff: $35 \mathrm{~mL}$ puff volume with $2 \mathrm{~s}$ duration at $60 \mathrm{~s}$ intervals (Heinr. Borgwaldt, Germany). Other apparatus used are as follows: $92 \mathrm{~mm}$ filter holder (part number 80206141) from Heinr. Borgwaldt, Germany; 44-mm Cambridge filter (CF) disposable assembly (part number 6004300) from Gelman Scientific, Ann Arbor, MI; glass impinger bottle with 24/40 female inlet and standard insert, $1.6 \mathrm{~mm}$ delivery orifice (PN PM030496) from Research Glass, Richmond, VA.

\section{Chemicals and reagents}

Deionized water $(18 \mathrm{M} \Omega \mathrm{cm}$ resistivity at room temperature) from Millipore-Q water purification system (Millipore Corp., Bedford, MA) was used for the preparation of the eluents and standards. Hydrochloric acid (Optima, assay $35.6 \%$ ) was obtained from Fisher Scientific, Atlanta, GA. Methanesulfonic acid (MSA, 99\%, M860-6) was obtained from Aldrich Chemical Co. Inc., Milwaukee, WI. Sulfuric acid $(95 \%)$ was obtained from EM Science, Gibbstown, NJ. Malic acid (99\%) was obtained from Eastman Kodak Company, Kingsport, TN.

\section{Standard preparation}

Ammonium chloride $\left(\mathrm{NH}_{4} \mathrm{Cl}\right)$ stock solution - The certified standard contained $100 \mu \mathrm{g} / \mathrm{mL} \pm 0.5 \%$ of $\mathrm{NH}_{4} \mathrm{Cl}$ in water (High-Purity Standards, Charleston, SC) was used "as is" without further purification.

Working standard solutions $(0.5,1,3,5 \mu \mathrm{g} / \mathrm{mL})$ - Four standard solutions were prepared by taking $0.5,1,3$, and 5 $\mathrm{mL}$ of the $100 \mu \mathrm{g} / \mathrm{mL}$ ammonium chloride stock solution using volumetric pipettes into four separate $100 \mathrm{~mL}$ volumetric flask and brought to volume with a $0.005 \mathrm{M} \mathrm{HCl}$ solution. The solutions were mixed well and stored in polyethylene bottles at room temperature for up to three months.

\section{Calibration curve preparation}

Four calibration standards with concentrations of $0.5,1,3$, and $5 \mu \mathrm{g} / \mathrm{mL}$ were injected at the beginning of each analytical run to prepare a calibration curve for $\mathrm{NH}_{3}$ analysis. The second order polynomial equation $\left(y=a x^{2}+\right.$ $b x+c$ ) was calculated using the regression program of Dionex PeakNet 5.1 software. Where $y=\mu \mathrm{g} / \mathrm{mL}$ of extracted $\mathrm{NH}_{4}{ }^{+}$and $x=$ integrated peak area for the sample from the IC analysis.

\section{Sample analysis}

Kentucky reference 1R4F cigarettes were used for the study. All of the tested cigarettes were conditioned at least $48 \mathrm{~h}$ at $24{ }^{\circ} \mathrm{C}$ and $60 \% \mathrm{RH}$ prior to smoking. The 20-port smoking machine was set up to receive the impinger trap containing $50 \mathrm{~mL}$ acidic solution and the $\mathrm{CF}$ was positioned in the inside cavity of the 20-port smoking machine (Figure 1). Silicon tubing was used to connect the outlet port located on the sealing segment of the smoking machine, the CF and impinger. MSS samples were generated from five conditioned $1 \mathrm{R} 4 \mathrm{~F}$ cigarettes with puffing para- 


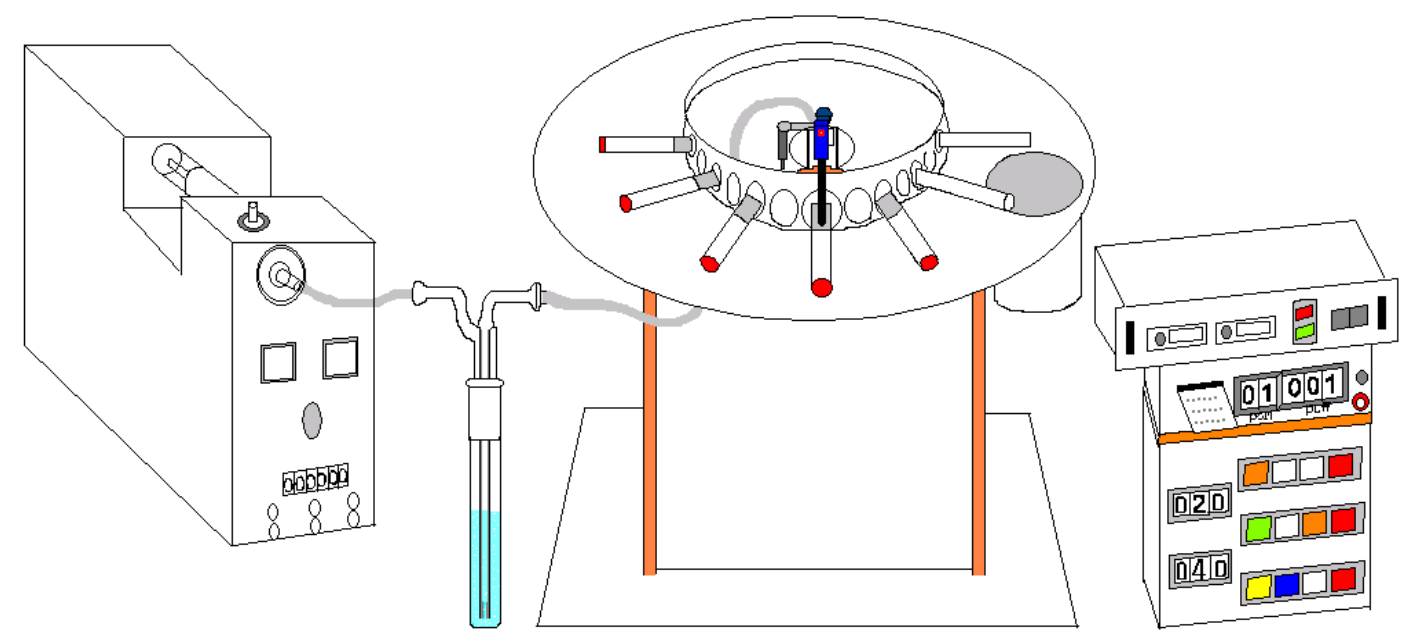

Figure 1. MSS setup for total ammonia analysis

Table 1. Ammonia content $(\mu \mathrm{g} / \mathrm{cig})$ in MSS

\begin{tabular}{lcc}
\hline Trapping solution & IonPac $® \mathrm{CS} 12$ & IonPac $\circledast \mathrm{CS} 12 \mathrm{~A}$ \\
\hline $0.005 \mathrm{M} \mathrm{HCl}$ at $30 \mathrm{~min}$ & $15.4 \pm 10 \%$ & $22.2 \pm 10 \%$ \\
$0.01 \mathrm{M} \mathrm{HCl}$ at $30 \mathrm{~min}$ & $13.1 \pm 10 \%$ & $19.8 \pm 10 \%$ \\
\hline
\end{tabular}

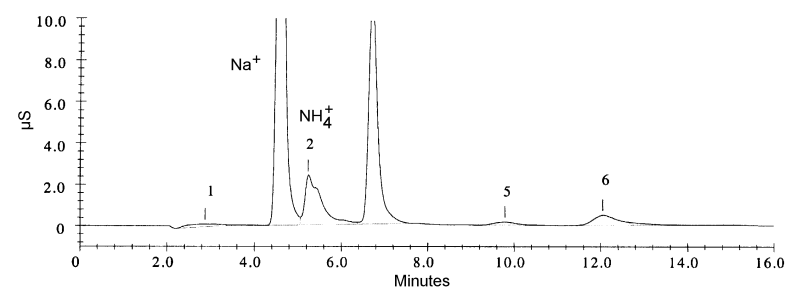

Figure 2. IC chromatogram - IonPac ${ }^{\circledR} \mathrm{CS} 12 \mathrm{~A}$ column with $22 \mathrm{mM} \mathrm{H}_{2} \mathrm{SO}_{4}$

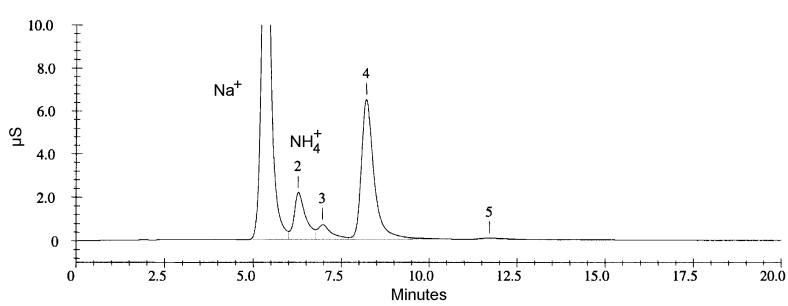

Figure 3. IC chromatogram - IonPac ${ }^{\circledR}$ CS12 column with 12 mM MSA

meters of 35-mL puffs of $2 \mathrm{~s}$ duration taken every $60 \mathrm{~s}$. Two blanks (whistle-through filter rods) were loaded after the sample cigarettes to provide clearing puffs. MSS was collected on a pre-weighed 44-mm CF. After smoking, the $\mathrm{CF}$ was re-weighed to record the total particulate matter (TPM). The CF pad was transferred into a $180 \mathrm{~mL}$ plastic flask and $50 \mathrm{~mL}$ trapping solution from the impinger was added. The mixture was stirred on a magnetic stirrer for 2 min. The extract was filtered using a $0.45 \mu \mathrm{m}$ filter into an autosampler vial for IC analysis.

\section{Calculations}

The analyte concentration is determined by an external standard method using a second order polynomial equation. A calibration curve is generated prior to sample analysis. The curve covers a calibrated range of 5 to $50 \mu \mathrm{g} / \mathrm{cig}$. Ammonia concentration is calculated using the following equation:

$$
=\frac{\mu \mathrm{g} / \mathrm{mL} \text { of } \mathrm{NH}_{4}^{+} \text {from readout } \times \mathrm{mL}(\text { volume of trap solution })}{\text { No. of cigarettes }} \times(17 / 18),
$$

where $17 / 18$ is used to convert $\mathrm{NH}_{4}^{+}(\mathrm{mw}=18)$ to $\mathrm{NH}_{3}$ $(\mathrm{mw}=17)$, since the calibration standards were prepared using ammonium chloride $\left(\mathrm{NH}_{4} \mathrm{Cl}\right)$.

\section{RESULTS AND DISCUSSION}

\section{Chromatography affect}

Three commercial ion chromatographic columns commonly used for ammonium ion analysis in various origins are Dionex IonPac ${ }^{\circledR}$ CS12, IonPac ${ }^{\circledR}$ CS12A and IonPac ${ }^{\circledR}$ CS15 $(5,6)$. In this study, two chromatographic conditions were investigated for ammonia contents in MSS of 1R4F cigarettes:

1) Dionex IonPac ${ }^{\circledR} \operatorname{CS} 12$ analytical column, IonPac $\AA$ CG12 $(4 \times 50 \mathrm{~mm})$ guard column, and $12 \mathrm{mM}$ MSA with $1.0 \mathrm{~mL} / \mathrm{min}$ flow rate.

2) Dionex IonPac $\AA$ CS $12 A$ analytical column, IonPac $\AA$ CG12A $(4 \times 50 \mathrm{~mm})$ guard column, and $22 \mathrm{mM}$ sulfuric acid with $1.0 \mathrm{~mL} / \mathrm{min}$ flow rate.

The major difference between these columns is the stationary phase functional groups. The functional groups for the IonPac ${ }^{\circledR}$ CS12 column are carboxylic acids while the stationary phase of IonPac $₫$ CS12A contains carboxylic acids and phosphonic acids.

According to the quantitation results in Table 1, the ammonia content received from IonPac ${ }^{\circledR}$ CS12A is higher than from IonPac ${ }^{\circ} \mathrm{CS} 12$. This is due to the poor separation of the ammonium peak (no. 2) and an unknown peak (no. 3) using the CS12A column with $22 \mathrm{mM} \mathrm{H}_{2} \mathrm{SO}_{4}$ as mobile phase (Figures 2 and 3). It seems that the Ionac $^{\circledR}$ CS12 




Figure 4. IC chromatogram - MSS ammonium trapped with $0.1 \mathrm{M} \mathrm{H}_{2} \mathrm{SO}_{4}$

column with a $0.005 \mathrm{MHCl}$ mobile phase provides a better chromatographic separation for ammonia analysis in MSS. However, an additional study suggests that the IonPac ${ }^{\circledR}$ CS12 column is not a good selection for ammonia analysis when more concentrated inorganic acids, such as $0.05 \mathrm{M}$ $\mathrm{HCl}$ and $0.1 \mathrm{M} \mathrm{H}_{2} \mathrm{SO}_{4}$ were used. The concentrated acid $\left(0.1 \mathrm{MH}_{2} \mathrm{SO}_{4}\right)$ generated a poor separation between sodium and ammonium peaks when the IonPac ${ }^{\circledR} \mathrm{CS} 12$ column was used (Figure 4).

\section{Stability of ammonia in trapping solution}

The stability of ammonia in the trapping solution was studied under various conditions. These conditions include the type of acid (hydrochloric acid, sulfuric acid and malic acid) and the strength of acidic solution (0.005 $M, 0.01 \mathrm{M}$ and $0.1 M$ ). Five 1R4F control cigarettes and 44-mm CF pads were used. The contents of ammonia in MSS samples were monitored from $2 \mathrm{~min}$ to $4 \mathrm{~h}$ at ambient temperature. The results indicate that the ammonia content steadily increased from $11 \mu \mathrm{g} / \mathrm{cig}$ to $18 \mu \mathrm{g} / \mathrm{cig}$ and stabilized in approximately an hour at ambient temperature (Figure 5). The type and concentration of acids was not significantly related to the total ammonia content in MSS. The ammonia content in MSS under different acids and concentrations was in approximately $10 \%$ deviation at the time when ammonium was measured.

\section{Trapping efficiency}

The trapping efficiency of MSS was investigated by regular CF pads (44 mm and $92 \mathrm{~mm}$ ), acid treated CF pads (92 $\mathrm{mm})$ and electrostatic precipitation (EP) tubes. The acid treated CF pads were obtained by treating regular $92-\mathrm{mm}$ CF pads with $15 \mathrm{~mL}$ of $1.5 \%$ ascorbic acid in methanol. The treated pads were air-dried in the open atmosphere prior to use. Two impingers containing $50 \mathrm{~mL} 0.005 \mathrm{M} \mathrm{HCl}$ or $45 \mathrm{~mL} 0.1 \mathrm{M}$ malic acid solution were connected to the CF pads or EP tube for breakthrough evaluation (Figure 1). After smoking, small volumes $(<1 \mathrm{~mL})$ of the trapping solution from each impinger were transferred to sample vials for analysis. Then the CF pad was extracted using the solution from the first impinger. Ammonia content in solutions of each impinger and the extract of the CF pad were quantitated using IonPac ${ }^{\circ}$ CS 12 column with $12 \mathrm{mM}$ MSA. Ammonia results listed in Table 2 revealed that the trapping efficiency of CF pad and EP tube for total ammonia in MSS is approximately $98-99 \%$. The first and second impingers trapped approximately $1-2 \%$ of ammonia. The study indicated that the size and type of the trapping device, such as CF pad, acid treated CF pad and the EP tube, did not significantly affect the trapping efficiency (Figure 6).

\section{CONCLUSIONS}

The examination of chromatographic conditions, stability of ammonium cations in acid solution and trapping efficiency suggested an improved sample preparation and analytical condition for the analysis of total ammonia content in MSS. The optimized parameters include the use of a weak inorganic acid (such as $0.005 \mathrm{M} \mathrm{HCl}$ ) as trapping solution, one-hour extraction of $\mathrm{CF}$ pad with the trapping solution, and analysis of the extract by IonPac $®$ CS 12 column with $12 \mathrm{mM}$ MSA as mobile phase. Even though we found only very low levels of ammonia breakthrough using the CF pad, an impinger containing acidic solution is recommended for trapping ammonia in MSS.

\section{REFERENCES}

1. Johnson, W.R., S.C. Clough, and P.H. Chen: Chemistry of the conversion of nitrate nitrogen to smoke products; Nature 243 (1973) 223-225.

2. Jenkins, R.A., M.R. Guerin, and B.A. Tomkins: The chemistry of environmental tobacco smoke: Composition and measurement; edited by M. Eisenberg, Lewis Publishers, $2^{\text {nd }}$ Edition, Chapter 3, 2000, pp. 49-75.

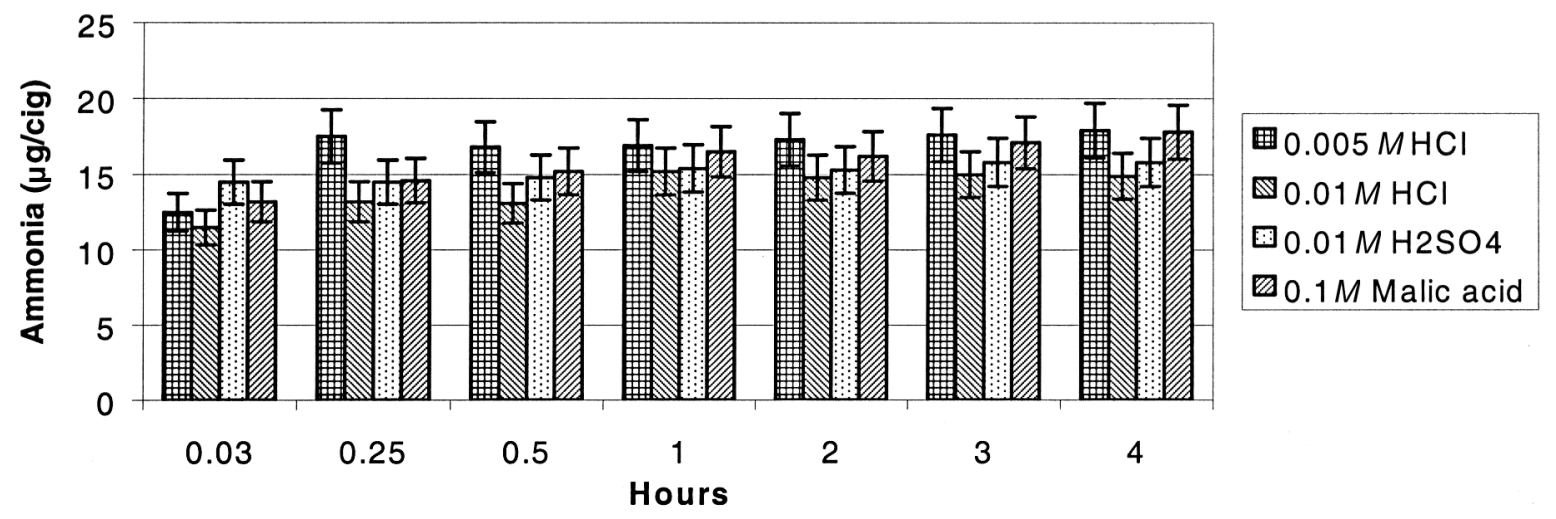

Figure 5. Ammonia stability study 
Table 2. Ammonia content $(\mu \mathrm{g} / \mathrm{cig})$ in impingers and CF pads

\begin{tabular}{|c|c|c|c|c|}
\hline Extracts & 44-mm CF & 92-mm CF & EP tube & 9- mm CF/acid \\
\hline 1st Impinger extract & 0.4 & 0.2 & 0.2 & 0.2 \\
\hline 2nd Impinger extract & 0.3 & 0.1 & 0.2 & 0.3 \\
\hline Extract-30 min (total) & $15.4 \pm 10 \%$ & $14.6 \pm 10 \%$ & $14.4 \pm 10 \%$ & $14.6 \pm 10 \%$ \\
\hline Extract-60 min (total) & $16.2 \pm 10 \%$ & $16.6 \pm 10 \%$ & $15.7 \pm 10 \%$ & $16.6 \pm 10 \%$ \\
\hline
\end{tabular}

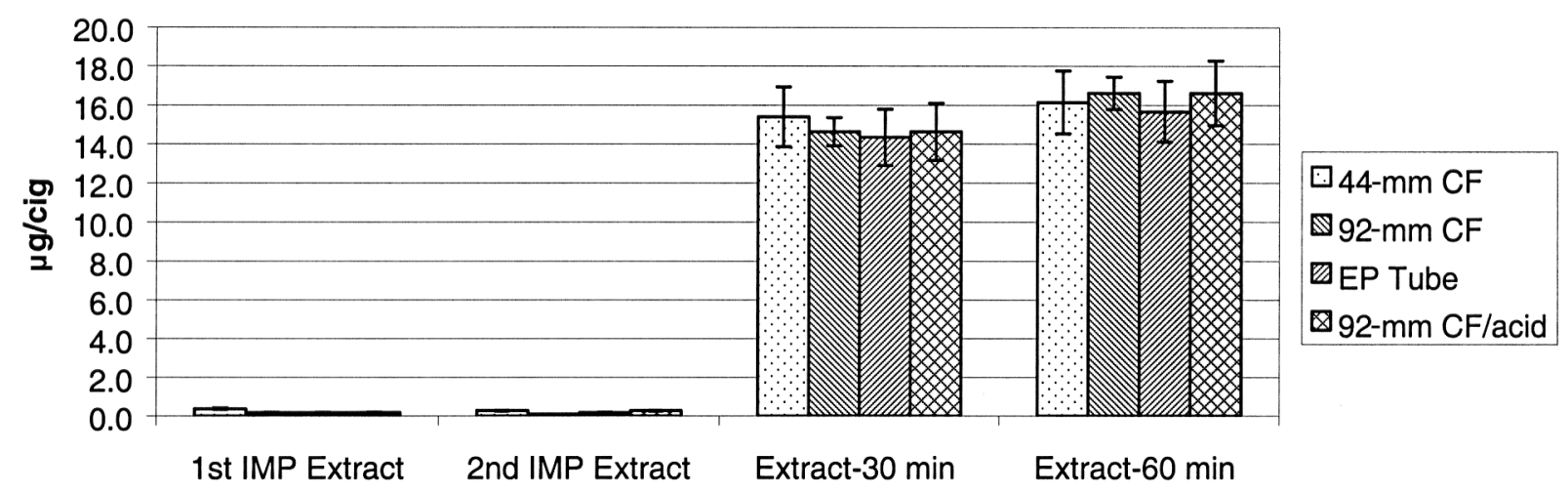

Figure 6. Trapping efficiency for total ammonia

3. Park, K.H and Y.K. Shin: Simple correlation of ammonia in smoke to the constituents of leaf tobacco; J. Korean Sco. Tob. Sci. 2 (1980) 78-82.

4. IARC Monographs on the evaluation of the carcinogenic risk of chemicals to humans: Tobacco smoking; IARC, Vol. 38, 1985, p. 95.

5. Pohl, C., M. Rey, D. Jensen, and J. Kerth: Determination of sodium and ammonium ions in disproportionate concentration ratios by ion chromatography; J. Chromatogr. A 850 (1999) 239-245.
6. Hodge, E.M., P. Martinez, and D. Sweetin: Determination of inorganic cations by ion chromatography; $\mathrm{J}$. Chromatogr. A. 884 (2000) 223-227.

Address for correspondence:

Chorng B. Huang

Philip Morris USA, RD \&E Center

P.O. Box 26583, Richmond, VA 23261, U.S.A.

E-mail:Chorng.B.Huang@pmusa.com

Fax: (804) 274-2886 